\title{
The Paradox of p53: What, How, and Why?
}

\author{
Yael Aylon and Moshe Oren \\ Department of Molecular Cell Biology, The Weizmann Institute of Science, Rehovot 76100, Israel \\ Correspondence: moshe.oren@weizmann.ac.il
}

Unlike the rather stereotypic image by which it was portrayed until not too many years ago, p53 is now increasingly emerging as a multifaceted transcription factor that can sometimes exert opposing effects on biological processes. This includes pro-survival activities that seem to contradict p53's canonical proapoptotic features, as well as opposing effects on cell migration, metabolism, and differentiation. Such antagonistic bifunctionality (balancing both positive and negative signals) bestows p53 with an ideal attribute to govern homeostasis. The molecular mechanisms underpinning the paradoxical activities of p53 may be related to a protein conformational spectrum (from canonical wild-type to "pseudomutant"), diversity of DNA response elements, and/or higher-order chromatin configuration. Altogether, this functional flexibility positions p53 as a transcriptional "super hub" that dictates cell homeostasis, and ultimately cell fate, by governing a hierarchy of other functional hubs. Deciphering the mechanisms by which p53 determines which hubs to engage, and how one might modulate the preferences of p53, remains a major challenge for both basic science and translational cancer medicine.

$\mathrm{T}_{\mathrm{o}}^{\mathrm{h}}$ hirty-five years ago, the arena of cancer biology was introduced to a new putative oncogene, p53 (Kress et al. 1979; Lane and Crawford 1979; Linzer and Levine 1979; Melero et al. 1979; Smith et al. 1979). However, one decade later, p53 was reincarnated as an ultimate tumor suppressor (Wolf and Rotter 1984; Baker et al. 1989; Eliyahu et al. 1989; Finlay et al. 1989; Oren 1992; Berns 1994), widely hailed for its ability to drive the apoptotic demise of cancer cells (Yonish-Rouach et al. 1991). Now, rebounding trends increasingly turn our attention to the fact that, at least in some biological contexts, p53 can actually unequivocally support cell survival, even if the beneficiary cell happens to be cancerous (Vousden and Prives 2009). Does this mean that p53 should now, once again, be con- sidered as an oncogene? Most probably not. Nevertheless, this tells us that we have to part with the old stereotypic image of p53 as a simple-minded tumor suppressor and come up with more sophisticated understanding of what exactly p53 does and for what purposes.

Some of the stereotypic perception of p53 is historically based, originating from the initially disappointing observation that p53 is seemingly dispensable for normal development (Donehower et al. 1992). Gratifyingly, p53-null mice were found to be more resilient to radiationinduced apoptosis (Clarke et al. 1993; Lowe et al. 1993). Consequently, p53 was studied for many years primarily in response to DNA damage or other acute "organism-threatening" conditions. This might have masked other, more

Editors: Guillermina Lozano and Arnold J. Levine

Additional Perspectives on The p53 Protein available at www.perspectivesinmedicine.org

Copyright (C) 2016 Cold Spring Harbor Laboratory Press; all rights reserved; doi: 10.1101/cshperspect.a026328

Cite this article as Cold Spring Harb Perspect Med 2015;6:a026328 
"mundane" attributes of p53. However, the current dogma is gradually shifting toward the concept that p53 may have the choice of regulating a variety of cellular processes either positively or negatively, thereby actively maintaining homeostasis under less dramatic but much more frequently encountered conditions. Thus, the celebrated "guardian of the genome" (Lane 1992) is evolving into the "guardian of homeostasis."

To realize its homeostatic agenda, p53 may paradoxically regulate the expression of genes exerting opposing effects on the same cellular process. In that regard, p53 can be envisioned as possessing a dynamic "sliding scale" of functions, ranging from canonical tumor suppressor attributes (e.g., pro-death, anti-cell migration, and quenching of reactive oxygen species [ROS]) to diametrically opposite activities that are typically associated with oncogenes (e.g., pro-survival, pro-migration, and induction of ROS). The term "antagonistic bifunctionality," describing paradoxical activities of a single molecule that enable more effective responses to changing conditions and thereby contribute to biological robustness, has been coined previously in studies of biological circuits (Hart and Alon 2013). It now appears that p53 may also belong to the growing family of regulatory molecules that qualify for this title. Yet, many questions still remain: "What" paradoxical cell processes does p53 regulate? How do the mechanics of paradoxical transactivation operate? And, why has evolution ended up relying seemingly on only one molecule for such crucial bidirectional choices? In fact, when viewed through these glasses, much of the literature is testament to the notion that p53 sometimes implements binary and paradoxical cell processes.

\section{WHAT DO WE MEAN BY "PARADOXICAL CELL PROCESSES"?}

Let us start off with apoptosis, as an example. p53 is a direct transactivator of a hoard of proapoptotic genes including $B A X$, the $\mathrm{BH} 3$-only genes PUMA and NOXA, the death receptors CD95, DR4, and DR5, and many more (Riley et al. 2008). However, proteins encoded by several p53 target genes actually can tone down or even inhibit apoptosis. The canonical p21 protein is perhaps the best-documented example (Polyak et al. 1996; Janicke et al. 2008), but the list also includes others such as $14-3-3 \sigma$, Plk2, Btg2, Btg3, and DDR (Rouault et al. 1996; Hermeking et al. 1997; Shimizu-Yoshida et al. 2001; Burns et al. 2003; Ongusaha et al. 2003; $\mathrm{Ou}$ et al. 2007). Although some of those genes serve primarily to elicit cell-cycle arrest and thereby indirectly spare the cells from death (Jones et al. 2005), others have overt pro-survival activities. Even in the former case, although cell-cycle arrest and apoptosis are superficially teleologically equivalent as effectors of tumor suppression, they differ greatly in that proliferation arrest may spare also damaged cells from a death sentence, potentially sowing the dormant seeds of cancer.

Another setting in which p53 may generate opposing outcomes is cell migration and wound healing. These programs underpin vital processes in multicellular organisms, ranging from embryonic development to aging. Cell migration can also be inappropriately activated during tumor progression, in which it serves as a key step in metastatic spread (Mego et al. 2010). Thus, it is perhaps no surprise that p53 "takes an interest" in these processes. Indeed, numerous studies support the notion that p53 inhibits cell migration, tissue renewal, and wound healing (Tyner et al. 2002; Schoppy et al. 2010; Muller et al. 2011). For instance, p53 represses epithelial-to-mesenchymal transition (EMT), an essential process in wound healing as well as a major driver of malignant progression in many types of cancer (Wang et al. 2009) by various mechanisms, including the transactivation of microRNAs of the miR-200 family, which target the EMT transcription factors ZEB1 and ZEB2 (Howe et al. 2011; Kim et al. 2011). Notably, p53 pathway hyperactivation accelerates tissue deterioration and promotes the appearance of ageassociated pathologies in mice (Tyner et al. 2002; Maier et al. 2004). This premature aging, potentially explainable by augmented attrition of adult stem cells (SCs), argues that sustained p53 engagement can present a significant barrier to tissue renewal. 
Paradoxically, p53 was also reported to facilitate tissue renewal and EMT in some settings (Kane and Greenhalgh 2000; Sablina et al. 2003; Nakade et al. 2004). For example, loss of p53 was shown to lead to severe defects in hair follicle regeneration and accelerated deterioration of the intestinal epithelium in mice with mosaic deletion of Atr (Ruzankina et al. 2009). Similarly, in a Pten;K-ras mouse model, p53 showed a positive role in ovarian cancer cell migration, as well as in survival (Mullany et al. 2012). This role for p53 in promoting cell migration, which appears to be at odds with its canonical perception, further highlights its antagonistic bifunctionality.

Homeostatic regulation of metabolism is emerging as a major function of p53. As such, p53 engages in intricate cross talk with master regulators of metabolism, such as mTOR and AMPK (AMP-activated protein kinase). Similar to apoptosis and migration, the metabolic impact of p53 is also highly context-dependent and may lead to confounding conclusions if one takes the facts at face value. For example, during energetic stress due to nutrient deprivation, AMPK can phosphorylate and activate p53 (Imamura et al. 2001; Jones et al. 2005). However, in high-glucose conditions, metformin-activated AMPK actually inhibits p53 (Nelson et al. 2012). The complexity does not end here, but extends also to the cross talk between p53 and mTOR. p53 restrains mTOR by transcriptionally activating the expression of an assortment of proteins, including the exemplary TOR inhibitor TSC2 (Feng et al. 2007). In some instances, p53-dependent mTOR inhibition is AMPK-dependent (Budanov et al. 2004; Feng et al. 2005). In turn, p53 can be inhibited by mTOR (Mungamuri et al. 2006), which makes good sense intuitively. However, under different conditions, p53 is actually up-regulated, rather than inhibited, by mTOR (Lee et al. 2007). Together, this complex regulatory network between mTOR, AMPK, and p53 modulates numerous aspects of cellular metabolism, including ROS, autophagy, and lipid metabolism (detailed in the following paragraphs).

Energy metabolism is intricately linked to production and neutralization of ROS (Sab- harwal and Schumacker 2014). p53 positively regulates the expression of antioxidant proteins, such as sestrins (Budanov et al. 2004), aldehyde dehydrogenase 4 (ALDH4) (Yoon et al. 2004), and TP53INP1 (Cano et al. 2009). Concurrently, p53 represses the expression of pro-oxidant genes such as nitric oxide synthase (NOS2) (Ambs et al. 1998) and cyclooxygenase 2 (COX2) (Subbaramaiah et al. 1999). Yet, on the other hand, p53 can augment cellular ROS by activating genes such as PIG3/TP53IP3, proline oxidase (PIG6/POX), and ferredoxin reductase (FDXR) (Polyak et al. 1997; Liu and Chen 2002; Rivera and Maxwell 2005) and inhibiting G6PDH, malic enzymes, and manganese superoxide dismutase (Zhao et al. 2005; Jiang et al. 2011, 2013). The generally accepted rationale behind these seemingly conflicting effects of p53 is that mild ROS induces a p53-dependent growth arrest and antioxidant response, whereas excessive ROS might be conducive to p53-dependent apoptosis (Kruiswijk et al. 2015). That being said, the question still remains as to the "design logic" of p53 governing the paradoxical pivot between these two opposing processes.

Autophagy is a lysosome-dependent catabolic pathway that recycles building blocks derived from long-lived proteins or damaged organelles. Like p53, autophagy can also exert opposing effects on cell fate. While serving as a survival mechanism under conditions of relatively mild or transient nutrient deprivation, allowing the cell to optimize the use of its limited resources, autophagy can also lead, in extreme cases, to cell death. At first glance, autophagy appears to be a tumor suppressive mechanism, because mice heterozygous for the autophagy gene Beclin1 are tumor-prone (Qu et al. 2003; Yue et al. 2003) and Beclin 1 deletions are associated with $40 \%-75 \%$ of sporadic human breast, ovarian, and prostate cancers (Aita et al. 1999). However, autophagy can also benefit cancer through its ability to protect tumor cells against metabolic stress, hypoxia, and antineoplastic therapies (Rouschop and Wouters 2009). Not surprisingly, p53 can both promote and inhibit autophagy (Morselli et al. 2009; Maiuri et al. 2010; Maddocks and Vousden 2011). This may be dependent on cell-type-specific subcel- 
lular distribution of p53 (Tasdemir et al. 2008), as well as on the cellular metabolic baseline, which differs greatly between normal and cancerous cells. Indeed, nutrient (amino acid) starvation has opposing effects on autophagic flux in p53-depleted mouse embryonic fibroblasts and in human colon carcinoma cells (ScherzShouval et al. 2010).

Furthermore, the cellular metabolic baseline itself may be influenced by p53. This is exemplified by the impact of p53 on lipogenic status. Thus, p53 regulates genes involved in lipid transport in the liver (Goldstein and Rotter 2012), and it also facilitates transport of fatty acids to the mitochondria to undergo catabolism (Zaugg et al. 2001). Moreover, under glucose starvation p53 induces LIPIN1, a key modulator of the fatty acid metabolism transcriptional regulators PGC1- $\alpha$, PPAR $\alpha$, and SREBP (Finck et al. 2006; Assaily et al. 2011). p53 can also directly repress the expression of $S R E B P 1 c$ and two of its lipogenic target genes, fatty acid synthase (FASN) and ATP citrate lyase (ACLY) (Yahagi et al. 2003). Importantly, many of those transcriptional effects are exerted by p53 also under basal conditions, in the absence of notable stress, thereby enabling p53 to finetune the lipid metabolic landscape of the pertinent cells and tissues.

Given that p53 keeps a tight rein on lipogenesis, it may not be surprising that it has been implicated in diseases related to lipid metabolism, such as type 2 diabetes, obesity, and hepatic steatosis (fatty liver disease) (Yahagi et al. 2003; Minamino et al. 2009; Liu et al. 2013). p53 is induced in the livers of mice suffering from hepatic steatosis (Yahagi et al. 2003, 2004) and chronic alcohol consumption (Derdak et al. 2011) and in adipocytes of obese mice (Yahagi et al. 2003). In these models, attenuation of p53 activity reduces disease by suppressing fat accumulation and liver damage (Derdak et al. 2013) and improving insulin sensitivity (Minamino et al. 2009). However, other studies suggest that p53 plays a protective role against the development of obesity, diabetes, and liver steatosis. When fed a high-fat diet, mice lacking p53 accumulate excessive hepatic lipids and body mass (Wang et al. 2013b). Moreover, the inability to properly activate p53 has been shown to increase metabolic stress. For instance, mice bearing an ATM-phosphorylation-resistant form of p53 develop insulin resistance and glucose intolerance (Armata et al. 2010). Complementary to this notion, "super-p53" mice, which express an extra copy of the p53 gene, benefit from superior glucose tolerance (Franck et al. 2012). These opposing effects of p53 deficiency on metabolic pathologies illustrate once more the bipolar nature of p53 and caution against a stereotypic description of the relationship between p53 and metabolism. Yet, they reinforce again the notion that p53 is a key regulator of metabolic homeostasis, not only at the cellular but also at the organismal level.

Another area of recent interest is the impact of p53 on stem cell differentiation. Here again, p53 facilitates some differentiation programs, while inhibiting others. Of note, several early studies have documented decreases in p53 protein and RNA levels during mouse embryonic stem cell (mESC) differentiation and mouse embryonic development in vivo (Chandrasekaran et al. 1981; Rogel et al. 1985; Sabapathy et al. 1997; Lin et al. 2005), which is thought to be coupled with decreased p53 transcriptional activity (Lin et al. 2005), cytoplasmic localization (Grandela et al. 2007; Qin et al. 2007; Han et al. 2008; Solozobova et al. 2009) and p53 conformational alterations (Sabapathy et al. 1997). Moreover, activation of p53 in mESCs counteracts differentiation by inducing various components of the WNT signaling pathway (Lee et al. 2010). In apparent contradiction to the above, several in vitro and in vivo models have shown that reexpression of $\mathrm{p} 53$ in p53-null undifferentiated mESCs drives them toward a more differentiated state (Sabapathy et al. 1997; Komarov et al. 1999; Lee et al. 2005). One possible mechanism that may account for a positive effect of p53 on differentiation has to do with the impact of p53 on the expression of Nanog, a protein essential for embryonic stem cell self-renewal and maintenance of pluripotency (Silva et al. 2009); in mESCs, direct suppression of Nanog by $\mathrm{p} 53$ is sufficient to drive differentiation (Lin et al. 2005). A plausible explanation for the seemingly discrepant effects of p53 on mESC 
The Paradox of p53: What, How, and Why?

differentiation is that differences in the signaling landscape of mESCs might modulate the ability of p53 to choose among different noncanonical transcription programs, with widely varying consequences for cell fate.

Adult SCs are necessary for normal tissue homoeostasis and are vital for regeneration after damage. Analogous to the situation in embryonic SCs, the proliferation, self-renewal, and differentiation status of adult SCs is also tightly controlled by p53. p53 exerts a positive influence on B-cell, neural, and myogenic differentiation (Shaulsky et al. 1991; Aloni-Grinstein et al. 1993; Montano 1997; Tamir and Bengal 1998; Hughes et al. 2000; Porrello et al. 2000; Cam et al. 2006; Zhang et al. 2006). Similarly, p53-null mammary glands from adult mice harbor increased numbers of undifferentiated SCs both in vivo (Jerry et al. 2000; Cicalese et al. 2009) and in vitro (Tao et al. 2011). One appealing mechanism for the p53-dependent maintenance of a limited pool of adult SCs is via the role of $\mathrm{p} 53$ in promoting asymmetric cell division (Cicalese et al. 2009); however, this is not the only way whereby p53 can encourage differentiation. Other mechanisms have been proposed to explain the positive effect of p53 on differentiation during the later stages of brown adipogenesis (Molchadsky et al. 2013) and in driving terminal differentiation of osteogenic cells (Radinsky et al. 1994).

In other settings, p53 actually appears to exert a negative effect on differentiation, resulting in the augmented differentiation of particular types of p53-null cells. This is exemplified by mesenchymal stem cells (MSCs). MSCs reside in the bone marrow and can differentiate into osteoblasts, adipocytes, and chondrocytes. When the balance of adipogenic or osteogenic factors is tipped, MSCs normally become committed toward a single lineage by activating lineage-specific transcription factors and repressing alternative lineage factors (Rosen and MacDougald 2006). Proper p53 function can be likened to a switchboard operator plugging-in environmental cues to drive and reinforce a suitable differentiation state. MSCs that lack p53 get their "wires crossed" and augment osteoblast differentiation markers Osterix and Runx2 (Lengner et al. 2006; Wang et al. 2006; Molchadsky et al. 2008; Rodriguez et al. 2009) concomitantly with inducing Pparg, a driver of adipocyte differentiation (Rodriguez et al. 2009). Thus, rather than simply serving as a positive regulator of differentiation, as one might expect from the well-documented inverse correlation between differentiation and cancer, p53 should be viewed also here as a moderator of differentiation homeostasis.

\section{HOW DO THE MECHANICS OF DIVERSE TRANSACTIVATION WORK?}

Conceivably, "alternative lifestyle" changes underpinning the paradoxical effects of p53 might be related to differences in p53 protein conformation. Point mutations in the p53 DNA-binding domain elicit conformational and functional instability (Joerger and Fersht 2007), strengthening the notion that correct folding of p53 is vital for its "proper" canonical functions. Furthermore, p53 that is wild type (WT) by sequence is not automatically WT by nature, and actually needs to maintain its WT conformation by binding to a variety of molecular chaperones, including CCT (chaperonin-containing $t$-complex polypeptide 1 ) (Trinidad et al. 2013; Rivlin et al. 2014) and HSP70 (Walerych et al. 2009). Conformational maintenance of p53 has been associated with phosphorylation within the p53 amino-terminal domain (Wang and Chen 2003). Interestingly, transforming growth factor (TGF)- $\beta$, a cytokine intimately involved in cell migration, signals through "noncanonical" mutant p53 in a manner that depends on p53 phosphorylation on amino-terminal residues (Cordenonsi et al. 2007).

Moreover, it stands to reason that the extensively studied mutant p53 gain of function (GOF) (Oren and Rotter 2010; Muller and Vousden 2014) may be an exaggerated reflection of transcriptional activities that are normally explored also by WT-p53 under defined conditions. Embedded within this concept is the notion that, at least in some cases, the WT-p53 that is retained in a substantial percentage of tumors may be structurally and functionally altered in 
a manner that converts it into a "pseudomutant” p53. In this way, such tumors may still reap the potential benefits of mutant p53 GOF even in the absence of TP53 gene mutations. Furthermore, some cancer-associated deregulated signaling pathways may force genetically WT-p53 to adopt "pseudomutant" properties, bypassing the selective pressure for TP53 mutations (Furth et al. 2015). However, when the signaling landscape of such cancer cells is profoundly altered (e.g., on exposure to acute stress), the canonical WT conformation of their p53 might be restored, reinstating a canonical p53 transcriptional program. This may explain why many gene expression studies using WTp53-positive cancer cells have repeatedly revealed canonical target genes rather than "altered p53" targets. The experimental design typically compared cells treated with genotoxic agents to their nontreated counterparts, rather than focusing on the transcriptional effects of the endogenous WT-p53 under basal conditions.

An alternative and not necessarily contradicting notion is that target gene divergence is due not just to altered p53 protein states, but also to built-in differences in p53 response elements. Several studies have focused on this issue in relation to $\mathrm{p} 53$ binding to cell cycle versus apoptotic gene promoters. It has been suggested that different binding affinities of p53 to the regulatory DNA elements of proapoptotic versus cell-cycle inhibitory genes might be crucial (Weinberg et al. 2005). However, although there is a tendency for the promoters of many proapoptotic genes to bind p53 less avidly, there are some that do harbor high-affinity p53 binding sites (Szak et al. 2001). A complementary notion suggests that regulation of the efficiency of RNA polymerase II engagement and transcriptional commitment to p53 target gene transactivation, as dictated by core promoter architecture, plays an important role in regulating differential gene expression (Morachis et al. 2010). More recently, a mechanism that combines the complementary impacts of the p53 protein state and the structure of its cognate DNA response elements has been described (Timofeev et al. 2013). Specifically, it has been shown that binding of $\mathrm{p} 53$ to proapoptotic target genes and transcriptional activation of those genes, both in vitro and in vivo, relies on cooperative interactions between adjacent DNAbinding domains within the p53 tetramer. Hence, conditions that affect the strength of those cooperative interactions may modulate the transcriptional program executed by p53, providing a possible explanation for opposing outcomes under different conditions.

Higher-order chromatin architecture is also an important feature in transcriptional regulation. The preexisting three-dimensional chromatin landscape of a particular cellular state is thought to be a stable structure that may predispose to induction of distinct sets of target genes (Jin et al. 2013). Recently, it has been shown that enhancer regions distant from the actual p53 target genes interact intrachromosomally with those target genes to convey longdistance p53-dependent transcriptional regulation (Melo et al. 2013; Allen et al. 2014). In this scenario, a single distal enhancer may coordinately turn on the expression of multiple target genes that interact with that enhancer. It is therefore tempting to speculate that state-specific changes in the higher-order organization and accessibility of such distal p53-regulated enhancers may allow the cell to switch between different p53 transcriptional programs without altering the immediate context of each individual target gene.

The vast majority of studies addressing the transcriptional roles of p53 have focused on genes that are transactivated by $\mathrm{p} 53$. Nevertheless, a comparable number of genes are actually repressed by $\mathrm{p} 53$. For technical reasons, investigation of p53-mediated transactivation is easier and more straightforward than the study of p53-mediated transcriptional repression and consequently has been more rewarding publication-wise. Yet, p53-mediated transcriptional repression may be of equal importance and remains an underexplored area that may still hide many exciting surprises. Unlike transactivation, transcriptional repression by p53 is often (with some notable exceptions) not elicited through direct binding of p53 to recognizable p53-binding sequences within the DNA. Instead, it typ- 
ically occurs via protein-protein interactions, which allows p53 to be recruited to specific genes by "piggybacking" on other transcription factors and DNA-binding proteins that recognize specific sequences within those genes. In doing so, p53 may obstruct pro-transcriptional interactions of its partners or recruit transcriptional corepressors such as Sin3a and histone deacetylases (Murphy et al. 1999; Ho and Benchimol 2003; Riley et al. 2008) to their binding sites. It is thus quite plausible that "altered" p53 interacts with a different repertoire of binding partners, which target it to a different panel of DNA response elements. This is likely to result in the repression of a different set of genes. The extent to which such "partner switching" contributes to the execution of "counterintuitive” programs by p53 is presently unknown and might provide interesting new insights.

For many years, p53 research has focused exclusively on the full-length (FL) p53, which has been characterized in great structural and functional detail. Nevertheless, there is growing recognition that alternative p53 isoforms (Bourdon et al. 2005), derived from the TP53 gene through the usage of multiple promoters, alternative translation initiation sites, and alternative splicing, possess a diverse range of biochemical and biological activities, including cancer-promoting activities (see Joruiz and Bourdon 2016). Changes in the relative abundance of p53 isoforms, which either augment or repress the transcriptional activity of coexpressed FL p53, have been implicated in cancer as well as in senescence and aging (Hafsi et al. 2013; Surget et al. 2013). As one example, the $\Delta 133$ p53 isoform inhibits senescence in normal human fibroblasts, whereas the $\mathrm{p} 53-\beta$ isoform promotes senescence (Fujita et al. 2009). In line with these observations, it has been proposed that increased $\Delta 133$ p53 and decreased $p 53-\beta$ expression in colon carcinomas may reflect an escape from the senescence barrier during progression from adenoma to carcinoma (Fujita et al. 2009). Recently, a new isoform, p53 $\Psi$, was shown to promote cell motility and invasion in a transcription-independent manner (Senturk et al. 2014), widening the "noncanonical" repertoire of p53. These multiple p53 isoforms, which increase greatly the level of complexity of p53-mediated transcription, might contribute significantly to the generation of discordant p53 programs.

As if matters were not complicated enough, p53 is only one member of an extended family of transcription factors, which includes also p63 and p73. Although superficially binding to the same consensus sites (Dotsch et al. 2010), each member of the family has its unique gene preferences, as illustrated also by the distinct phenotypes of p53, p63, and p73 knockout mice (Murray-Zmijewski et al. 2006).

Together, the combination of these many regulatory variables may have more impact than previously appreciated and may provide a logical mechanistic framework for the apparent antagonistic bifunctionality (and probably multifunctionality) of p53.

\section{WHY RELY ON ONLY ONE MOLECULE FOR BIDIRECTIONAL PROCESSES?}

Cells continuously adapt to changing conditions to maintain homeostasis by altering gene expression. By analogy to architectural blueprints, gene expression patterns can be envisaged as networks in which transcription factors and their target genes are pictured as nodes, connected to each other via hubs. This is thought to confer a hierarchical structure, whereby hubs play a central role in directing the cellular response to a given stimulus. Importantly, the number of extensively connected central hubs is far below that of hubs with few connections. The fact that most nodes make only a small number of significant connections renders a biological network more robust and less sensitive to noise (Shoval and Alon 2010). Another characteristic of transcriptional networks is that they facilitate efficient propagation and integration of signals by creating pathways in which very few "steps" are necessary to join any two nodes (Blais and Dynlacht 2005).

Within this framework, p53 might be viewed as a "super hub," modulating the expression of numerous and varied secondary hubs and thus commanding a profound impact on 
cell fate (Vogelstein et al. 2000). The p53 isoforms and p53 family members, p73 and p63, are all players in the same regulatory network. So, indeed, p53 is connected to (almost) everything. This network architecture, which positions p53 as a critical "input sensor" that safeguards against perturbations and equips p53 with an exceptionally powerful toolbox to fine-tune its own activities, is highly advantageous for maintaining homeostasis.

Of note, the concept of transcriptional hubs is not at odds with the aforementioned molecular mechanisms proposed for differential activation of distinct transcriptional programs by p53. Altered states of WT-p53 with a "sliding scale" of functions might be capable of differentially engaging specific hubs, distinct p53binding DNA response elements might define functional hubs, and higher-order chromatin architecture might physically confine a subset of functional hubs.

Opposing transcriptional outputs of p53 might be defined by the distinct number of steps that signals need to travel to generate a particular output. Moreover, in stress conditions there may be a reordering of hub hierarchy, bringing certain hubs more closely to p53 and thus decreasing the number of necessary steps. This setup most likely has implications for the kinetics of differential gene transcription. Under regular physiological conditions, associated with manageable mild and transient stress, p53 may engage proximal and immediate hubs. Manageable stresses include, for example, reparable transient DNA damage or fluctuations in oxygen or nutrient availability. These represent a potential challenge to homeostasis, and p53 appropriately responds by inducing a transient cell-cycle arrest (proliferation hubs). Alternatively, p53 might induce antioxidant responses, metabolic remodeling or promotion of catabolism (metabolic hubs). These adaptive responses allow cells to survive safely until the challenge to homeostasis has been satisfactorily resolved. In contrast, p53 might be situated more distantly from apoptotic hubs, which might take longer to fully engage. This is in line with the kinetics of p53 transactivation in vivo. Although p53 can bind promoters of both cell-cycle and pro- apoptotic genes very rapidly, transcription of proapoptotic targets is impeded for hours after p53 binding, suggesting slow kinetics of engagement of rate-limiting factors needed to transactivate those genes (Szak et al. 2001). This suggests that resolution of the stress within an acceptable time window, before all apoptotic factors are fully in place, may dampen the prodeath signal and reinstate homeostasis without risking the irreversible consequences of avoidable cell death.

Similar mechanisms of staggered kinetics might be built also into other p53-regulated discordant processes. For instance, it is conceivable that in wound healing p53 might initially engage pro-migratory, pro-EMT hubs while orchestrating a subsequent wave of more distal anti-EMT hubs to complete the resolution phase of the wound healing process. This is in line with the explicit need to precisely regulate the EMT response temporally in normal cells, because dampening of the delayed or "distant" hub might be exploited by cancer to generate "a wound that does not heal" (Dvorak 1986).

Protracted p53 activation, and perhaps the resulting imbalance between immediate and delayed discordant transcriptional programs, appears to have a negative impact on homeostasis. For instance, whereas basal levels of p53 facilitate the maintenance of glucose tolerance and protect from metabolic disease, chronic activation of p53 (similar to that which occurs in response to sustained metabolic stress due to excess glucose or obesity) has been shown to contribute to glucose intolerance (Hinault et al. 2011). Likewise, signal-independent persistent p53 activation can promote the aging process (Tyner et al. 2002; Maier et al. 2004; Dumble et al. 2007).

Another implication of the p53 "super hub" conjecture is that cells lacking p53 may be particularly unable to tolerate perturbations to homeostasis. This is exemplified by the observation that individuals with $\mathrm{Li}$-Fraumeni familial cancer syndrome (LFS), harboring a heterozygous TP53 germline mutation, suffer from metabolic disorders in addition to their high risk of developing cancer (Wang et al. 2013a). Indeed, perturbation of homeostasis is an inherent and 
defining feature of cancer. The centrality of p53 for tumor suppression is dramatically illustrated by the fact that it is the most frequently mutated gene in human cancer (Petitjean et al. 2007). Thus, the disadvantage of "super hubs" is the hypersensitivity of the system to inactivation of the decisive indispensible hub, as occurs upon TP53 mutation. The fact that this potentially vulnerable network architecture has nevertheless persisted through evolution implies that the benefit of relying on a single bifunctional molecule must somehow outweigh the above disadvantage, with its associated increased cancer risk.

What other architectural benefits are built into the p53 module? Specifically, what functional benefit might be achieved by maintaining p53 as a single paradoxical component rather than splitting the two opposing functions into distinct components? In bacteria, maintaining enzymes with bifunctionality (e.g., enzymes that can act both as kinases and as phosphatases [Capra and Laub 2012]) has been shown to enable robustness within a regulatory circuit (Shinar et al. 2007). In other words, for bacteria, changes in the concentration of any of the components will not change the phosphorylationdephosphorylation ratio (Hart and Alon 2013). Analogously, p53 bifunctionality might ensure that the balance between pro-survival and antisurvival outputs would remain robust despite minor perturbations within the circuit. This would allow accurate control of homeostasis in the face of naturally occurring fluctuations in upstream signals or in the concentrations of metabolites and oxygen.

An additional benefit of such network design might be exerted during more severe stress, when energy conservation, speed of response, and coherence of response are essential. Using a multifunctional single component is energyefficient in times of genotoxic or excessive nutrient stress, averting the need to consume valuable resources that otherwise would be needed to synthesize new proteins. Reusing resources also ensures a more rapid response than synthesizing and assembling fresh transcriptional transactivators. Last, relying on a single molecule for two paradoxical programs has the dual benefit of inducing the desired output while simultaneously diverting stimulation from undesired transcriptional targets.

Interestingly, the bifunctionality of p53 seems to have gone through selective pressure in the course of evolution. Thus, p53 has coevolved functions in maintaining genomic integrity in the face of genotoxic stress (Levine et al. 2011) together with its pro-survival activities (Rutkowski et al. 2011). As a further illustration, the p53 homologs in Caenorhabditis elegans and Drosophila dually regulate apoptosis and glucose metabolism (Mandal et al. 2005; Belyi et al. 2010).

Of note, evolutionary selection for bifunctionality is not limited to $\mathrm{p} 53$ and appears to be a common feature of many apoptosis-related molecules, For example, c-IAP1 is most widely known as an antiapoptotic factor; however, the cleaved carboxy-terminal domain of c-IAP1 actually has proapoptotic activity (Clem et al. 2001). Similarly, full-length BID has a proproliferation activity (Bai et al. 2005) and can serve as a DNA damage sensor to participate in protective cell-cycle arrest (Kamer et al. 2005; Zinkel et al. 2005), but the cleaved form of BID $(\mathrm{t}-\mathrm{BID})$ acts as a potent pro-death molecule (Gross et al. 1999).

More than 35 years after its discovery, and despite close to 80,000 pertinent scientific publications, the "paradox" of p53 is still far from being resolved. Can we develop the computational, technological, and biological tools to tackle this "super hub" challenge? Can we work together to overcome our current scientific biases and identify true patterns in the huge piles of data? Only the next 35 years will tell. But be ready for new surprises!

\section{ACKNOWLEDGMENTS}

The research performed in the authors' laboratory is supported in part by a Center of Excellence Grant (1779/11) from the Israel Science Foundation, research grants from the Dr. Miriam and Sheldon G. Adelson Medical Research Foundation, the Robert Bosch Stiftung, The Germany Israel Foundation (GIF), the Estate of John Hunter, and the Moross Integrated 
Cancer Center. M.O. is incumbent of the Andre Lwoff Chair in Molecular Biology.

\section{REFERENCES}

${ }^{*}$ Reference is also in this collection.

Aita VM, Liang XH, Murty VV, Pincus DL, Yu W, Cayanis E, Kalachikov S, Gilliam TC, Levine B. 1999. Cloning and genomic organization of beclin 1, a candidate tumor suppressor gene on chromosome 17q21. Genomics 59: 59-65.

Allen MA, Andrysik Z, Dengler VL, Mellert HS, Guarnieri A, Freeman JA, Sullivan KD, Galbraith MD, Luo X, Kraus WL, et al. 2014. Global analysis of p53-regulated transcription identifies its direct targets and unexpected regulatory mechanisms. eLife 3: $\mathrm{e} 02200$.

Aloni-Grinstein R, Zan-Bar I, Alboum I, Goldfinger N, Rotter V. 1993. Wild type p53 functions as a control protein in the differentiation pathway of the B-cell lineage. Oncogene 8: 3297-3305.

Ambs S, Merriam WG, Ogunfusika MO, Bennett WP, Ishibe N, Hussain SP, Tzeng EE, Geller DA, Billiar TR, Harris CC. 1998. p53 and vascular endothelial growth factor regulate tumor growth of NOS2-expressing human carcinoma cells. Nat Med 4: 1371-1376.

Armata HL, Golebiowski D, Jung DY, Ko HJ, Kim JK, Sluss HK. 2010. Requirement of the ATM/p53 tumor suppressor pathway for glucose homeostasis. Mol Cell Biol 30: 5787-5794.

Assaily W, Rubinger DA, Wheaton K, Lin Y, Ma W, Xuan W, Brown-Endres L, Tsuchihara K, Mak TW, Benchimol S. 2011. ROS-mediated p53 induction of Lpin1 regulates fatty acid oxidation in response to nutritional stress. Mol Cell 44: 491-501.

Bai L, Ni HM, Chen X, DiFrancesca D, Yin XM. 2005. Deletion of Bid impedes cell proliferation and hepatic carcinogenesis. Am J Pathol 166: 1523-1532.

Baker SJ, Fearon ER, Nigro JM, Hamilton SR, Preisinger AC, Jessup JM, vanTuinen P, Ledbetter DH, Barker DF, Nakamura Y, et al. 1989. Chromosome 17 deletions and p53 gene mutations in colorectal carcinomas. Science 244: 217-221.

Belyi VA, Ak P, Markert E, Wang H, Hu W, Puzio-Kuter A, Levine AJ. 2010. The origins and evolution of the p53 family of genes. Cold Spring Harb Perspect Biol 2: a001198.

Berns A. 1994. Cancer genetics. Is p53 the only real tumor suppressor gene? Curr Biol 4: 137-139.

Blais A, Dynlacht BD. 2005. Constructing transcriptional regulatory networks. Genes Dev 19: 1499-1511.

Bourdon JC, Fernandes K, Murray-Zmijewski F, Liu G, Diot A, Xirodimas DP, Saville MK, Lane DP. 2005. p53 isoforms can regulate 533 transcriptional activity. Genes Dev 19: $2122-2137$.

Budanov AV, Sablina AA, Feinstein E, Koonin EV, Chumakov PM. 2004. Regeneration of peroxiredoxins by p53-regulated sestrins, homologs of bacterial AhpD. Science 304: 596-600.

Burns TF, Fei P, Scata KA, Dicker DT, El-Deiry WS. 2003. Silencing of the novel p53 target gene Snk/Plk2 leads to mitotic catastrophe in paclitaxel (taxol)-exposed cells Mol Cell Biol 23: 5556-5571.

Cam H, Griesmann H, Beitzinger M, Hofmann L, Beinoraviciute-Kellner R, Sauer M, Huttinger-Kirchhof N, Oswald C, Friedl P, Gattenlohner S, et al. 2006. p53 family members in myogenic differentiation and rhabdomyosarcoma development. Cancer Cell 10: 281-293.

Cano CE, Gommeaux J, Pietri S, Culcasi M, Garcia S, Seux M, Barelier S, Vasseur S, Spoto RP, Pebusque MJ, et al. 2009. Tumor protein 53-induced nuclear protein 1 is a major mediator of p53 antioxidant function. Cancer Res 69: $219-226$.

Capra EJ, Laub MT. 2012. Evolution of two-component signal transduction systems. Annu Rev Microbiol 66: 325-347.

Chandrasekaran K, McFarland VW, Simmons DT, Dziadek M, Gurney EG, Mora PT. 1981. Quantitation and characterization of a species-specific and embryo stage-dependent 55-kilodalton phosphoprotein also present in cells transformed by simian virus 40. Proc Natl Acad Sci 78: 6953-6957.

Cicalese A, Bonizzi G, Pasi CE, Faretta M, Ronzoni S, Giulini B, Brisken C, Minucci S, Di Fiore PP, Pelicci PG. 2009. The tumor suppressor p53 regulates polarity of self-renewing divisions in mammary stem cells. Cell 138: $1083-$ 1095.

Clarke AR, Purdie CA, Harrison DJ, Morris RG, Bird CC, Hooper ML, Wyllie AH. 1993. Thymocyte apoptosis induced by p 53 -dependent and independent pathways. $\mathrm{Na}$ ture 362: 849-852.

Clem RJ, Sheu TT, Richter BW, He WW, Thornberry NA, Duckett CS, Hardwick JM. 2001. c-IAP1 is cleaved by caspases to produce a proapoptotic C-terminal fragment. J Biol Chem 276: 7602-7608.

Cordenonsi M, Montagner M, Adorno M, Zacchigna L, Martello G, Mamidi A, Soligo S, Dupont S, Piccolo S. 2007. Integration of TGF- $\beta$ and Ras/MAPK signaling through p53 phosphorylation. Science 315: 840-843.

Derdak Z, Lang CH, Villegas KA, Tong M, Mark NM, de la Monte SM, Wands JR. 2011. Activation of p53 enhances apoptosis and insulin resistance in a rat model of alcoholic liver disease. J Hepatol 54: 164-172.

Derdak Z, Villegas KA, Harb R, Wu AM, Sousa A, Wands JR. 2013. Inhibition of p53 attenuates steatosis and liver injury in a mouse model of non-alcoholic fatty liver disease. J Hepatol 58: 785-791.

Donehower LA, Harvey M, Slagle BL, McArthur MJ, Montgomery CA Jr, Butel JS, Bradley A. 1992. Mice deficient for p53 are developmentally normal but susceptible to spontaneous tumours. Nature 356: 215-221.

Dotsch V, Bernassola F, Coutandin D, Candi E, Melino G. 2010. p63 and p73, the ancestors of p53. Cold Spring Harb Perspect Biol 2: a004887.

Dumble M, Moore L, Chambers SM, Geiger H, Van Zant G, Goodell MA, Donehower LA. 2007. The impact of altered p53 dosage on hematopoietic stem cell dynamics during aging. Blood 109: 1736-1742.

Dvorak HF. 1986. Tumors: Wounds that do not heal. Similarities between tumor stroma generation and wound healing. N Engl J Med 315: 1650-1659. 
Eliyahu D, Michalovitz D, Eliyahu S, Pinhasi-Kimhi O, Oren M. 1989. Wild-type p53 can inhibit oncogene-mediated focus formation. Proc Natl Acad Sci 86: 8763-8767.

Feng Z, Zhang H, Levine AJ, Jin S. 2005. The coordinate regulation of the p53 and mTOR pathways in cells. Proc Natl Acad Sci 102: 8204-8209.

Feng Z, Hu W, de Stanchina E, Teresky AK, Jin S, Lowe S, Levine AJ. 2007. The regulation of AMPK $\beta 1$, TSC2, and PTEN expression by p53: Stress, cell and tissue specificity, and the role of these gene products in modulating the IGF-1-AKT-mTOR pathways. Cancer Res 67: 3043-3053.

Finck BN, Gropler MC, Chen Z, Leone TC, Croce MA, Harris TE, Lawrence JC Jr, Kelly DP. 2006. Lipin 1 is an inducible amplifier of the hepatic PGC- $1 \alpha /$ PPAR $\alpha$ regulatory pathway. Cell Metab 4: 199-210.

Finlay CA, Hinds PW, Levine AJ. 1989. The p53 proto-oncogene can act as a suppressor of transformation. Cell 57: $1083-1093$.

Franck D, Tracy L, Armata HL, Delaney CL, Jung DY, Ko HJ, Ong H, Kim JK, Scrable H, Sluss HK. 2012. Glucose tolerance in mice is linked to the dose of the p53 transactivation domain. Endocr Res doi: 10.3109/ 07435800.2012.735735.

Fujita K, Mondal AM, Horikawa I, Nguyen GH, Kumamoto K, Sohn JJ, Bowman ED, Mathe EA, Schetter AJ, Pine SR, et al. 2009. p53 isoforms $\Delta 133$ p53 and p53 $\beta$ are endogenous regulators of replicative cellular senescence. Nat Cell Biol 11: 1135-1142.

Furth N, Bossel Ben-Moshe N, Pozniak Y, Porat Z, Geiger T, Domany E, Aylon Y, Oren M. 2015. Down-regulation of LATS kinases alters p53 to promote cell migration. Genes Dev 29: 2325-2330.

Goldstein I, Rotter V. 2012. Regulation of lipid metabolism by p53-Fighting two villains with one sword. Trends Endocrinol Metab 23: 567-575.

Grandela C, Pera MF, Grimmond SM, Kolle G, Wolvetang EJ. 2007. p53 is required for etoposide-induced apoptosis of human embryonic stem cells. Stem Cell Res 1: 116128.

Gross A, Yin XM, Wang K, Wei MC, Jockel J, Milliman C, Erdjument-Bromage H, Tempst P, Korsmeyer SJ. 1999. Caspase cleaved BID targets mitochondria and is required for cytochrome $c$ release, while BCL- $\mathrm{X}_{\mathrm{L}}$ prevents this release but not tumor necrosis factor-R1/Fas death. $J$ Biol Chem 274: 1156-1163.

Hafsi H, Santos-Silva D, Courtois-Cox S, Hainaut P. 2013. Effects of $\Delta 40 \mathrm{p} 53$, an isoform of p53 lacking the N-terminus, on transactivation capacity of the tumor suppressor protein p53. BMC Cancer 13: 134.

Han MK, Song EK, Guo Y, Ou X, Mantel C, Broxmeyer HE. 2008. SIRT1 regulates apoptosis and Nanog expression in mouse embryonic stem cells by controlling p53 subcellular localization. Cell Stem Cell 2: 241-251.

Hart Y, Alon U. 2013. The utility of paradoxical components in biological circuits. Mol Cell 49: 213-221.

Hermeking H, Lengauer C, Polyak K, He TC, Zhang L, Thiagalingam S, Kinzler KW, Vogelstein B. 1997. 14-3$3 \sigma$ is a p53-regulated inhibitor of $\mathrm{G} 2 / \mathrm{M}$ progression. $\mathrm{Mol}$ Cell 1: 3-11

Hinault C, Kawamori D, Liew CW, Maier B, Hu J, Keller SR, Mirmira RG, Scrable H, Kulkarni RN. 2011. $\Delta 40$ Isoform of p53 controls $\beta$-cell proliferation and glucose homeostasis in mice. Diabetes 60: $1210-1222$.

Ho J, Benchimol S. 2003. Transcriptional repression mediated by the p53 tumour suppressor. Cell Death Differ 10: 404-408.

Howe EN, Cochrane DR, Richer JK. 2011. Targets of miR200c mediate suppression of cell motility and anoikis resistance. Breast Cancer Res 13: R45.

Hughes AL, Gollapudi L, Sladek TL, Neet KE. 2000. Mediation of nerve growth factor-driven cell cycle arrest in PC12 cells by p53. Simultaneous differentiation and proliferation subsequent to p53 functional inactivation. $J$ Biol Chem 275: 37829-37837.

Imamura K, Ogura T, Kishimoto A, Kaminishi M, Esumi H. 2001. Cell cycle regulation via p53 phosphorylation by a $5^{\prime}$-AMP activated protein kinase activator, 5 -aminoimidazole-4-carboxamide-1- $\beta$-D-ribofuranoside, in a human hepatocellular carcinoma cell line. Biochem Biophys Res Commun 287: 562-567.

Janicke RU, Sohn D, Schulze-Osthoff K. 2008. The dark side of a tumor suppressor: Anti-apoptotic p53. Cell Death Differ 15: 959-976.

Jerry DJ, Kittrell FS, Kuperwasser C, Laucirica R, Dickinson ES, Bonilla PJ, Butel JS, Medina D. 2000. A mammaryspecific model demonstrates the role of the p53 tumor suppressor gene in tumor development. Oncogene 19: 1052-1058.

Jiang P, Du W, Wang X, Mancuso A, Gao X, Wu M, Yang X. 2011. p53 regulates biosynthesis through direct inactivation of glucose-6-phosphate dehydrogenase. Nat Cell Biol 13: $310-316$.

Jiang P, Du W, Mancuso A, Wellen KE, Yang X. 2013. Reciprocal regulation of p53 and malic enzymes modulates metabolism and senescence. Nature 493: 689-693.

Jin F, Li Y, Dixon JR, Selvaraj S, Ye Z, Lee AY, Yen CA, Schmitt AD, Espinoza CA, Ren B. 2013. A high-resolution map of the three-dimensional chromatin interactome in human cells. Nature 503: 290-294.

Joerger AC, Fersht AR. 2007. Structural biology of the tumor suppressor $\mathrm{p} 53$ and cancer-associated mutants. Adv Cancer Res 97: 1-23.

Jones RG, Plas DR, Kubek S, Buzzai M, Mu J, Xu Y, Birnbaum MJ, Thompson CB. 2005. AMP-activated protein kinase induces a p53-dependent metabolic checkpoint. Mol Cell 18: 283-293.

* Joruiz SM, Bourdon J-C. 2016. p53 isoforms: Key regulators of the cell fate decision. Cold Spring Harb Perspect Med doi: 10.1101/cshperspect.a026039.

Kamer I, Sarig R, Zaltsman Y, Niv H, Oberkovitz G, Regev L, Haimovich G, Lerenthal Y, Marcellus RC, Gross A. 2005. Proapoptotic BID is an ATM effector in the DNA-damage response. Cell 122: 593-603.

Kane CD, Greenhalgh DG. 2000. Expression and localization of $\mathrm{p} 53$ and bcl-2 in healing wounds in diabetic and nondiabetic mice. Wound Repair Regen 8: 45-58.

Kim T, Veronese A, Pichiorri F, Lee TJ, Jeon YJ, Volinia S, Pineau P, Marchio A, Palatini J, Suh SS, et al. 2011. p53 regulates epithelial-mesenchymal transition through microRNAs targeting ZEB1 and ZEB2. J Exp Med 208: 875-883. 
Komarov PG, Komarova EA, Kondratov RV, Christov-Tselkov K, Coon JS, Chernov MV, Gudkov AV. 1999. A chemical inhibitor of p53 that protects mice from the side effects of cancer therapy. Science 285: 1733-1737.

Kress M, May E, Cassingena R, May P. 1979. Simian virus 40-transformed cells express new species of proteins precipitable by anti-simian virus 40 tumor serum. J Virol 31: $472-483$.

Kruiswijk F, Labuschagne CF, Vousden KH. 2015. p53 in survival, death and metabolic health: A lifeguard with a licence to kill. Nat Rev Mol Cell Biol 16: 393-405.

Lane DP. 1992. Cancer. p53, guardian of the genome. Nature 358: $15-16$.

Lane DP, Crawford LV. 1979. T antigen is bound to a host protein in SV40-transformed cells. Nature 278: 261-263.

Lee MK, Hande MP, Sabapathy K. 2005. Ectopic mTERT expression in mouse embryonic stem cells does not affect differentiation but confers resistance to differentiationand stress-induced p53-dependent apoptosis. J Cell Sci 118: 819-829.

Lee CH, Inoki K, Karbowniczek M, Petroulakis E, Sonenberg N, Henske EP, Guan KL. 2007. Constitutive mTOR activation in TSC mutants sensitizes cells to energy starvation and genomic damage via p53. EMBO J 26: 4812 4823.

Lee KH, Li M, Michalowski AM, Zhang X, Liao H, Chen L, Xu Y, Wu X, Huang J. 2010. A genomewide study identifies the Wnt signaling pathway as a major target of p53 in murine embryonic stem cells. Proc Natl Acad Sci 107: 69-74.

Lengner CJ, Steinman HA, Gagnon J, Smith TW, Henderson JE, Kream BE, Stein GS, Lian JB, Jones SN. 2006. Osteoblast differentiation and skeletal development are regulated by Mdm2-p53 signaling. J Cell Biol 172: 909-921.

Levine AJ, Tomasini R, McKeon FD, Mak TW, Melino G 2011. The p53 family: Guardians of maternal reproduction. Nat Rev Mol Cell Biol 12: 259-265.

Lin T, Chao C, Saito S, Mazur SJ, Murphy ME, Appella E, Xu Y. 2005. p53 induces differentiation of mouse embryonic stem cells by suppressing Nanog expression. Nat Cell Biol 7: $165-171$.

Linzer DI, Levine AJ. 1979. Characterization of a 54K dalton cellular SV40 tumor antigen present in SV40-transformed cells and uninfected embryonal carcinoma cells. Cell 17: 43-52.

Liu G, Chen X. 2002. The ferredoxin reductase gene is regulated by the p 53 family and sensitizes cells to oxidative stress-induced apoptosis. Oncogene 21: 7195-7204.

Liu K, Lou J, Wen T, Yin J, Xu B, Ding W, Wang A, Liu D, Zhang C, Chen D, et al. 2013. Depending on the stage of hepatosteatosis, $\mathrm{p} 53$ causes apoptosis primarily through either DRAM-induced autophagy or BAX. Liver Int 33: 1566-1574.

Lowe SW, Schmitt EM, Smith SW, Osborne BA, Jacks T. 1993. p53 is required for radiation-induced apoptosis in mouse thymocytes. Nature 362: 847-849.

Maddocks OD, Vousden KH. 2011. Metabolic regulation by p53. J Mol Med (Berl) 89: 237-245.

Maier B, Gluba W, Bernier B, Turner T, Mohammad K, Guise T, Sutherland A, Thorner M, Scrable H. 2004.
Modulation of mammalian life span by the short isoform of p53. Genes Dev 18: 306-319.

Maiuri MC, Galluzzi L, Morselli E, Kepp O, Malik SA, Kroemer G. 2010. Autophagy regulation by p53. Curr Opin Cell Biol 22: 181-185.

Mandal S, Guptan P, Owusu-Ansah E, Banerjee U. 2005. Mitochondrial regulation of cell cycle progression during development as revealed by the tenured mutation in Drosophila. Dev Cell 9: 843-854.

Mego M, Mani SA, Cristofanilli M. 2010. Molecular mechanisms of metastasis in breast cancer-Clinical applications. Nat Rev Clin Oncol 7: 693-701.

Melero JA, Stitt DT, Mangel WF, Carroll RB. 1979. Identification of new polypeptide species $(48-55 \mathrm{~K})$ immunoprecipitable by antiserum to purified large Tantigen and present in SV40-infected and -transformed cells. Virology 93: $466-480$.

Melo CA, Drost J, Wijchers PJ, van de Werken H, de Wit E, Oude Vrielink JA, Elkon R, Melo SA, Leveille N, Kalluri R, et al. 2013. eRNAs are required for p53-dependent enhancer activity and gene transcription. Mol Cell 49: 524535.

Minamino T, Orimo M, Shimizu I, Kunieda T, Yokoyama M, Ito T, Nojima A, Nabetani A, Oike Y, Matsubara H, et al. 2009. A crucial role for adipose tissue p53 in the regulation of insulin resistance. Nat Med 15: 1082-1087.

Molchadsky A, Shats I, Goldfinger N, Pevsner-Fischer M, Olson M, Rinon A, Tzahor E, Lozano G, Zipori D, Sarig $\mathrm{R}$, et al. 2008. p53 plays a role in mesenchymal differentiation programs, in a cell fate dependent manner. PLoS ONE 3: e3707.

Molchadsky A, Ezra O, Amendola PG, Krantz D, KoganSakin I, Buganim Y, Rivlin N, Goldfinger N, Folgiero V, Falcioni R, et al. 2013. p53 is required for brown adipogenic differentiation and has a protective role against diet-induced obesity. Cell Death Differ 20: 774-783.

Montano X. 1997. p53 associates with trk tyrosine kinase. Oncogene 15: 245-256.

Morachis JM, Murawsky CM, Emerson BM. 2010. Regulation of the p53 transcriptional response by structurally diverse core promoters. Genes Dev 24: 135-147.

Morselli E, Galluzzi L, Kepp O, Vicencio JM, Criollo A, Maiuri MC, Kroemer G. 2009. Anti- and pro-tumor functions of autophagy. Biochim Biophys Acta 1793: 1524-1532.

Mullany LK, Liu Z, King ER, Wong KK, Richards JS. 2012. Wild-type tumor repressor protein 53 ( $\operatorname{Trp53})$ promotes ovarian cancer cell survival. Endocrinology 153: 1638 1648.

Muller PA, Vousden KH. 2014. Mutant p53 in cancer: New functions and therapeutic opportunities. Cancer Cell 25: 304-317.

Muller PA, Vousden KH, Norman JC. 2011. p53 and its mutants in tumor cell migration and invasion. J Cell Biol 192: 209-218.

Mungamuri SK, Yang X, Thor AD, Somasundaram K. 2006. Survival signaling by Notch1: Mammalian target of rapamycin (mTOR)-dependent inhibition of p53. Cancer Res 66: 4715-4724.

Murphy M, Ahn J, Walker KK, Hoffman WH, Evans RM, Levine AJ, George DL. 1999. Transcriptional repression 
by wild-type p53 utilizes histone deacetylases, mediated by interaction with mSin3a. Genes Dev 13: $2490-2501$.

Murray-Zmijewski F, Lane DP, Bourdon JC. 2006. p53/p63/ p73 isoforms: An orchestra of isoforms to harmonise cell differentiation and response to stress. Cell Death Differ 13: $962-972$.

Nakade K, Zheng H, Ganguli G, Buchwalter G, Gross C, Wasylyk B. 2004. The tumor suppressor p53 inhibits Net, an effector of Ras/extracellular signal-regulated kinase signaling. Mol Cell Biol 24: 1132-1142.

Nelson LE, Valentine RJ, Cacicedo JM, Gauthier MS, Ido Y, Ruderman NB. 2012. A novel inverse relationship between metformin-triggered AMPK-SIRT1 signaling and p53 protein abundance in high glucose-exposed HepG2 cells. Am J Physiol Cell Physiol 303: C4-C13.

Ongusaha PP, Kim JI, Fang L, Wong TW, Yancopoulos GD, Aaronson SA, Lee SW. 2003. p53 induction and activation of DDR1 kinase counteract p53-mediated apoptosis and influence $\mathrm{p} 53$ regulation through a positive feedback loop. EMBO J 22: 1289-1301.

Oren M. 1992. p53: The ultimate tumor suppressor gene? FASEB J 6: 3169-3176.

Oren M, Rotter V. 2010. Mutant p53 gain-of-function in cancer. Cold Spring Harb Perspect Biol 2: a001107.

Ou YH, Chung PH, Hsu FF, Sun TP, Chang WY, Shieh SY. 2007. The candidate tumor suppressor BTG3 is a transcriptional target of p53 that inhibits E2F1. EMBO J 26: 3968-3980.

Petitjean A, Mathe E, Kato S, Ishioka C, Tavtigian SV, Hainaut P, Olivier M. 2007. Impact of mutant p53 functional properties on TP53 mutation patterns and tumor phenotype: Lessons from recent developments in the IARC TP53 database. Hum Mutat 28: 622-629.

Polyak K, Waldman T, He TC, Kinzler KW, Vogelstein B. 1996. Genetic determinants of p53-induced apoptosis and growth arrest. Genes Dev 10: 1945-1952.

Polyak K, Xia Y, Zweier JL, Kinzler KW, Vogelstein B. 1997. A model for p53-induced apoptosis. Nature 389: 300-305.

Porrello A, Cerone MA, Coen S, Gurtner A, Fontemaggi G, Cimino L, Piaggio G, Sacchi A, Soddu S. 2000. p53 regulates myogenesis by triggering the differentiation activity of pRb. J Cell Biol 151: 1295-1304.

Qin H, Yu T, Qing T, Liu Y, Zhao Y, Cai J, Li J, Song Z, Qu X, Zhou P, et al. 2007. Regulation of apoptosis and differentiation by p53 in human embryonic stem cells. J Biol Chem 282: 5842-5852.

Qu X, Yu J, Bhagat G, Furuya N, Hibshoosh H, Troxel A, Rosen J, Eskelinen EL, Mizushima N, Ohsumi Y, et al. 2003. Promotion of tumorigenesis by heterozygous disruption of the beclin 1 autophagy gene. J Clin Invest 112: 1809-1820.

Radinsky R, Fidler IJ, Price JE, Esumi N, Tsan R, Petty CM, Bucana CD, Bar-Eli M. 1994. Terminal differentiation and apoptosis in experimental lung metastases of human osteogenic sarcoma cells by wild type p53. Oncogene 9: 1877-1883.

Riley T, Sontag E, Chen P, Levine A. 2008. Transcriptional control of human p53-regulated genes. Nat Rev Mol Cell Biol 9: 402-412.
Rivera A, Maxwell SA. 2005. The p53-induced gene-6 (proline oxidase) mediates apoptosis through a calcineurindependent pathway. J Biol Chem 280: 29346-29354.

Rivlin N, Katz S, Doody M, Sheffer M, Horesh S, Molchadsky A, Koifman G, Shetzer Y, Goldfinger N, Rotter V, et al. 2014. Rescue of embryonic stem cells from cellular transformation by proteomic stabilization of mutant p53 and conversion into WT conformation. Proc Natl Acad Sci 111: 7006-7011.

Rodriguez R, Rubio R, Masip M, Catalina P, Nieto A, de la Cueva T, Arriero M, San Martin N, de la Cueva E, Balomenos D, et al. 2009. Loss of p53 induces tumorigenesis in p21-deficient mesenchymal stem cells. Neoplasia 11: 397-407.

Rogel A, Popliker M, Webb CG, Oren M. 1985. p53 cellular tumor antigen: Analysis of mRNA levels in normal adult tissues, embryos, and tumors. Mol Cell Biol 5: 28512855.

Rosen ED, MacDougald OA. 2006. Adipocyte differentiation from the inside out. Nat Rev Mol Cell Biol 7: 885-896.

Rouault JP, Falette N, Guehenneux F, Guillot C, Rimokh R, Wang Q, Berthet C, Moyret-Lalle C, Savatier P, Pain B, et al. 1996. Identification of BTG2, an antiproliferative p53dependent component of the DNA damage cellular response pathway. Nat Genet 14: 482-486.

Rouschop KM, Wouters BG. 2009. Regulation of autophagy through multiple independent hypoxic signaling pathways. Curr Mol Med 9: 417-424.

Rutkowski R, Dickinson R, Stewart G, Craig A, Schimpl M, Keyse SM, Gartner A. 2011. Regulation of Caenorhabditis elegans p53/CEP-1-dependent germ cell apoptosis by Ras/MAPK signaling. PLoS Genet 7: e1002238.

Ruzankina Y, Schoppy DW, Asare A, Clark CE, Vonderheide RH, Brown EJ. 2009. Tissue regenerative delays and synthetic lethality in adult mice after combined deletion of Atr and Trp53. Nat Genet 41: 1144-1149.

Sabapathy K, Klemm M, Jaenisch R, Wagner EF. 1997. Regulation of ES cell differentiation by functional and conformational modulation of p53. EMBO J 16: 6217-6229.

Sabharwal SS, Schumacker PT. 2014. Mitochondrial ROS in cancer: Initiators, amplifiers or an Achilles' heel? Nat Rev Cancer 14: 709-721.

Sablina AA, Chumakov PM, Kopnin BP. 2003. Tumor suppressor p53 and its homologue p73 $\alpha$ affect cell migration. J Biol Chem 278: 27362-27371.

Scherz-Shouval R, Weidberg H, Gonen C, Wilder S, Elazar $Z$, Oren M. 2010. p53-dependent regulation of autophagy protein LC3 supports cancer cell survival under prolonged starvation. Proc Natl Acad Sci 107: 18511-18516.

Schoppy DW, Ruzankina Y, Brown EJ. 2010. Removing all obstacles: A critical role for $\mathrm{p} 53$ in promoting tissue renewal. Cell Cycle 9: 1313-1319.

Senturk S, Yao Z, Camiolo M, Stiles B, Rathod T, Walsh AM, Nemajerova A, Lazzara MJ, Altorki NK, Krainer A, et al. 2014. p $53 \Psi$ is a transcriptionally inactive p53 isoform able to reprogram cells toward a metastatic-like state. Proc Natl Acad Sci 111: E3287-E3296.

Shaulsky G, Goldfinger N, Rotter V. 1991. Alterations in tumor development in vivo mediated by expression of wild type or mutant p53 proteins. Cancer Res 51: 5232-5237. 
Shimizu-Yoshida Y, Sugiyama K, Rogounovitch T, Ohtsuru A, Namba H, Saenko V, Yamashita S. 2001. Radiationinducible $h S N K$ gene is transcriptionally regulated by $\mathrm{p} 53$ binding homology element in human thyroid cells. Biochem Biophys Res Commun 289: 491-498.

Shinar G, Milo R, Martinez MR, Alon U. 2007. Input-output robustness in simple bacterial signaling systems. Proc Natl Acad Sci 104: 19931-19935.

Shoval O, Alon U. 2010. SnapShot: Network motifs. Cell 143: 326-e321.

Silva J, Nichols J, Theunissen TW, Guo G, van Oosten AL, Barrandon O, Wray J, Yamanaka S, Chambers I, Smith A. 2009. Nanog is the gateway to the pluripotent ground state. Cell 138: 722-737.

Smith AE, Smith R, Paucha E. 1979. Characterization of different tumor antigens present in cells transformed by simian virus 40. Cell 18: 335-346.

Solozobova V, Rolletschek A, Blattner C. 2009. Nuclear accumulation and activation of $\mathrm{p} 53$ in embryonic stem cells after DNA damage. BMC Cell Biol 10: 46.

Subbaramaiah K, Michaluart P, Chung WJ, Tanabe T, Telang N, Dannenberg AJ. 1999. Resveratrol inhibits cyclooxygenase-2 transcription in human mammary epithelial cells. Ann NY Acad Sci 889: 214-223.

Surget S, Khoury MP, Bourdon JC. 2013. Uncovering the role of p53 splice variants in human malignancy: A clinical perspective. Onco Targets Ther 7: 57-68.

Szak ST, Mays D, Pietenpol JA. 2001. Kinetics of p53 binding to promoter sites in vivo. Mol Cell Biol 21: 3375-3386.

Tamir Y, Bengal E. 1998. p53 protein is activated during muscle differentiation and participates with $\mathrm{MyoD}$ in the transcription of muscle creatine kinase gene. Oncogene 17: 347-356.

Tao L, Roberts AL, Dunphy KA, Bigelow C, Yan H, Jerry DJ. 2011. Repression of mammary stem/progenitor cells by p53 is mediated by Notch and separable from apoptotic activity. Stem Cells 29: 119-127.

Tasdemir E, Maiuri MC, Galluzzi L, Vitale I, DjavaheriMergny M, D’Amelio M, Criollo A, Morselli E, Zhu C, Harper F, et al. 2008. Regulation of autophagy by cytoplasmic p53. Nat Cell Biol 10: 676-687.

Timofeev O, Schlereth K, Wanzel M, Braun A, Nieswandt B, Pagenstecher A, Rosenwald A, Elsasser HP, Stiewe T. 2013. p53 DNA binding cooperativity is essential for apoptosis and tumor suppression in vivo. Cell Rep 3: 1512-1525.

Trinidad AG, Muller PA, Cuellar J, Klejnot M, Nobis M, Valpuesta JM, Vousden KH. 2013. Interaction of p53 with the CCT complex promotes protein folding and wild-type p53 activity. Mol Cell 50: 805-817.

Tyner SD, Venkatachalam S, Choi J, Jones S, Ghebranious N, Igelmann $\mathrm{H}, \mathrm{Lu} \mathrm{X}$, Soron G, Cooper B, Brayton C, et al. 2002. p53 mutant mice that display early ageing-associated phenotypes. Nature 415: 45-53.

Vogelstein B, Lane D, Levine AJ. 2000. Surfing the p53 network. Nature 408: 307-310.

Vousden KH, Prives C. 2009. Blinded by the light: The growing complexity of p53. Cell 137: 413-431.

Walerych D, Olszewski MB, Gutkowska M, Helwak A, Zylicz M, Zylicz A. 2009. Hsp70 molecular chaperones are required to support p53 tumor suppressor activity under stress conditions. Oncogene 28: 4284-4294.
Wang C, Chen J. 2003. Phosphorylation and hsp90 binding mediate heat shock stabilization of p53. J Biol Chem 278: 2066-2071.

Wang X, Kua HY, Hu Y, Guo K, Zeng Q, Wu Q, Ng HH, Karsenty G, de Crombrugghe B, Yeh J, et al. 2006. p53 functions as a negative regulator of osteoblastogenesis, osteoblast-dependent osteoclastogenesis, and bone remodeling. J Cell Biol 172: 115-125.

Wang SP, Wang WL, Chang YL, Wu CT, Chao YC, Kao SH, Yuan A, Lin CW, Yang SC, Chan WK, et al. 2009. p53 controls cancer cell invasion by inducing the MDM2mediated degradation of Slug. Nat Cell Biol 11: 694-704.

Wang PY, Ma W, Park JY, Celi FS, Arena R, Choi JW, Ali QA, Tripodi DJ, Zhuang J, Lago CU, et al. 2013a. Increased oxidative metabolism in the Li-Fraumeni syndrome. $\mathrm{N}$ Engl J Med 368: 1027-1032.

Wang X, Zhao X, Gao X, Mei Y, Wu M. 2013b. A new role of p53 in regulating lipid metabolism. J Mol Cell Biol 5: $147-150$.

Weinberg RL, Veprintsev DB, Bycroft M, Fersht AR. 2005. Comparative binding of p53 to its promoter and DNA recognition elements. J Mol Biol 348: 589-596.

Wolf D, Rotter V. 1984. Inactivation of p53 gene expression by an insertion of Moloney murine leukemia virus-like DNA sequences. Mol Cell Biol 4: 1402-1410.

Yahagi N, Shimano H, Matsuzaka T, Najima Y, Sekiya M, Nakagawa Y, Ide T, Tomita S, Okazaki H, Tamura Y, et al. 2003. p53 activation in adipocytes of obese mice. J Biol Chem 278: 25395-25400.

Yahagi N, Shimano H, Matsuzaka T, Sekiya M, Najima Y, Okazaki S, Okazaki H, Tamura Y, Iizuka Y, Inoue N, et al 2004. p53 involvement in the pathogenesis of fatty liver disease. J Biol Chem 279: 20571-20575.

Yonish-Rouach E, Resnitzky D, Lotem J, Sachs L, Kimchi A, Oren M. 1991. Wild-type p53 induces apoptosis of myeloid leukaemic cells that is inhibited by interleukin-6. Nature 352: 345-347.

Yoon KA, Nakamura Y, Arakawa H. 2004. Identification of ALDH4 as a p53-inducible gene and its protective role in cellular stresses. J Hum Genet 49: 134-140.

Yue Z, Jin S, Yang C, Levine AJ, Heintz N. 2003. Beclin 1, an autophagy gene essential for early embryonic development, is a haploinsufficient tumor suppressor. Proc Natl Acad Sci 100: 15077-15082.

Zaugg K, Rocha S, Resch H, Hegyi I, Oehler C, Glanzmann C, Fabbro D, Bodis S, Pruschy M. 2001. Differential p53dependent mechanism of radiosensitization in vitro and in vivo by the protein kinase $\mathrm{C}$-specific inhibitor PKC412. Cancer Res 61: 732-738.

Zhang J, Yan W, Chen X. 2006. p53 is required for nerve growth factor-mediated differentiation of PC12 cells via regulation of TrkA levels. Cell Death Differ 13: $2118-$ 2128.

Zhao Y, Chaiswing L, Velez JM, Batinic-Haberle I, Colburn NH, Oberley TD, St Clair DK. 2005. p53 translocation to mitochondria precedes its nuclear translocation and targets mitochondrial oxidative defense protein-manganese superoxide dismutase. Cancer Res 65: 3745-3750.

Zinkel SS, Hurov KE, Ong C, Abtahi FM, Gross A, Korsmeyer SJ. 2005. A role for proapoptotic BID in the DNAdamage response. Cell 122: 579-591. 


\section{$\&_{\mathrm{CSH}}^{\infty} \&$ Cold Spring Harbor

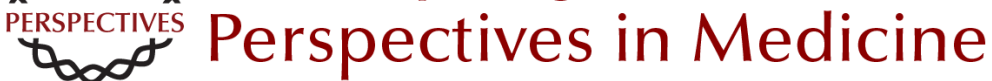

\section{The Paradox of p53: What, How, and Why?}

Yael Aylon and Moshe Oren

Cold Spring Harb Perspect Med 2016; doi: 10.1101/cshperspect.a026328 originally published online July 13, 2016

\section{Subject Collection The p53 Protein}

Targeting the MDM2-p53 Protein-Protein Interaction for New Cancer Therapy: Progress and Challenges

Shaomeng Wang, Yujun Zhao, Angelo Aguilar, et al.

Structural Evolution and Dynamics of the p53

Proteins

Giovanni Chillemi, Sebastian Kehrloesser,

Francesca Bernassola, et al.

Exploiting the p53 Pathway for Therapy Chit Fang Cheok and David Philip Lane

The Regulation of Cellular Functions by the p53 Protein: Cellular Senescence

Crystal A. Tonnessen-Murray, Guillermina Lozano and James G. Jackson

The Transactivation Domains of the p53 Protein Nitin Raj and Laura D. Attardi

The Evolution of the Ribosomal Protein-MDM2p53 Pathway

Chad Deisenroth, Derek A. Franklin and Yanping Zhang

Somatic TP53 Mutations in the Era of Genome

Sequencing

Pierre Hainaut and Gerd P. Pfeifer

The Paradox of p53: What, How, and Why? Yael Aylon and Moshe Oren
Control of Cellular Aging, Tissue Function, and Cancer by p53 Downstream of Telomeres Caitlin M. Roake and Steven E. Artandi

Inherited TP53 Mutations and the Li -Fraumeni Syndrome

Tanya Guha and David Malkin

TP53 Mutations in Hypodiploid Acute Lymphoblastic Leukemia

Evan Q. Comeaux and Charles G. Mullighan

Transcriptional Regulation by Wild-Type and

Cancer-Related Mutant Forms of p53

Neil T. Pfister and Carol Prives

The Inherited p53 Mutation in the Brazilian Population

Maria Isabel Achatz and Gerard P. Zambetti

TP53 Mutations in Breast and Ovarian Cancer Laxmi Silwal-Pandit, Anita Langerød and Anne-Lise Børresen-Dale

p53 and the Carcinogenicity of Chronic Inflammation

Andrei V. Gudkov and Elena A. Komarova

Oncogenic Mutant p53 Gain of Function

Nourishes the Vicious Cycle of Tumor

Development and Cancer Stem-Cell Formation

Yoav Shetzer, Alina Molchadsky and Varda Rotter

For additional articles in this collection, see http://perspectivesinmedicine.cshlp.org/cgi/collection/ 